\title{
Site Investigation Of Road Drains For Rural Road On Batu Pahat Soft Clay (BPSC)
}

\author{
Ahmad Hakimi Mat Nor ${ }^{1}$, Mohd Idrus Hj Mohd Masirin ${ }^{2}$ \\ and Mohd Erwan Sanik ${ }^{3}$
}

\begin{abstract}
Road failures may be caused by many factors. In Batu Pahat district, open channel system is adopted and built on Batu Pahat Soft Soil and may be a crucial factor to probable damage of the rural roads structure. This study is focused on the drainage system for rural roads in Parit Raja, Batu Pahat. The type of damages is observed and the causes are identified. Recommendations on the best method are made to improve the effectiveness of current drainage system. Both site and laboratory geotechnical testing are carried out to analyze the causes of failure to the drainage system. Laboratory testing such as sieve analysis, moisture content, Atterberg limit, specific gravity and shear strength are conducted. While Mackintosh probes testing and vane shear test are conducted for site testing. From the analysis, four categories of drainage failure such as soil movement, edge drop, cracking and erosion due to the characteristics of soft clay that have low shear strength and high compatibility, have been determined. The propose methods to increase the effectiveness of the drainage system are to stabilize the soil using geotextiless, combination geotextiless and geocontainers, soil anchor and lime.
\end{abstract}

Keywords: Batu Pahat Soft Clay, Drainage Failure, Geotechnical Testing, Road Failures, Rural Road

\section{Introduction}

Road is important for land communication. In rural areas, road is important mean to deliver agriculture products. Therefore, when rural roads experience damages like pothole, muddy, and slippery after rainy season, it directly affect the safety, economy and social life of the users. Not forgetting that the performance of roads also depends on its drainage system. Drainage system is very crucial in controlling the surface runoff and to avoid adverse affect to roads. The main function of drainage is to direct the surface flow to catchments area like river, lake and sea. If the drainage system is not well designed and maintained, rural road will rapidly be damaged or will seriously lead to floods and reduce road design life (Liang, 2001).

Open drainage system for rural roads is common in Batu Pahat district. From the random observations, it was found that some of drainage system for rural roads are facing deformation and are not functioning as expected. Structure failures of rural road caused by failure on drainage system constructed on Batu Pahat Soft Soil (BPSC) was also observed. Figure 1 shows the example of impact from road drainage structure failure in Parit Raja road. This problem has shortened the life span of rural roads. Normally maintenance works are done by only resurfacing the pavement. However, this approach has not solved the problems (Abdul Rahim, 2005).

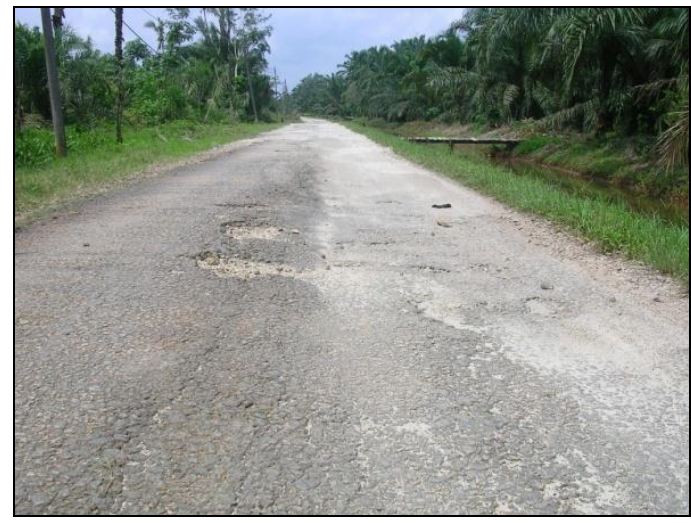

Figure 1: Impact from road drainage structure failure for rural road in Parit Raja

\footnotetext{
${ }^{1}$ Instructor Engineer, Universiti Tun Hussein Onn Malaysia, 86400 Parit Raja, Johor, MALAYSIA

${ }^{2}$ Professor, Universiti Tun Hussein Onn Malaysia, 86400 Parit Raja, Johor, MALAYSIA

${ }^{3}$ Senior Instructor Engineer, Universiti Tun Hussein Onn Malaysia, 86400 Parit Raja, Johor, MALAYSIA
} 
Effective maintenance works are important if based on the factors that lead to the failures. Mohd Idrus (2006) have found that more than $30 \%$ of rural roads in Batu Pahat district experienced deteriorations due to the various factors. In this study, the identification of the causes and effects of drainage failures are carried out. Recommendation to upgrade the current drainage system constructed on BPSC is proposed. Figure 2 shows the example of improper maintenance for rural road.

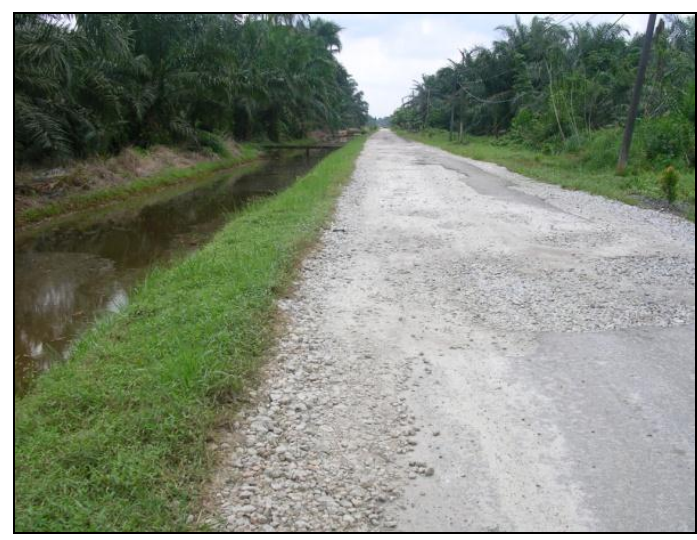

Figure 2: Improper maintenance for rural road

According to Brand and Brenner (1981), clay consists of tiny particles which size is less than $2 \mu \mathrm{m}$. Clay comprises of complex colloidal particle, with the diameter from several micron to hundred microns. Minerals in clay are silicate, feldspar, oxide, hydroxide, liquid aluminum, carbonate, and organic matter. Clay particle is in pieces which greasy and sticky when in wet condition and hard when in dry condition. Its thickness is relatively small when compared to its length and surface area. Flodin and Broms (1981) defined the soft clay is the clay that have the shear strength less than $25 \mathrm{kPa}$. Construction on soft clay will typically face to the problems of settlement and stability. Soft clay has high compressibility and sensitivity where movement on top of it will disturb the soil properties. Humidity of soft clay is not less than $85 \%$.

The aim of this research is to conduct site investigation of open-earth roadside drains for rural roads which are constructed on BPSC. The main objectives of this study are as follows:

a) To identify and investigate the causes of failure for current drainage system from selected rural roads which are constructed on soft clay in Batu Pahat district.

b) To study effects of drainage failures on rural roads constructed on BPSC.

c) To conclude the causes of drainage failures and propose the best method to increase the effectiveness of current drainage system on BPSC.

\begin{abstract}
II. Methodology
Road inspection for rural road using pavement condition survey

The inspection is carried out to determine the types of failures which occurred on the surface of the road pavement and to find value of road pavement condition index (PCI). Therefore, the level of road pavement performances can be observed. Besides that, the relationship between the road pavement failures and drainage failures can be studied. In order to detect the failure of drainage system, types of roads and drainage failures should first be identified. The checking process is done based on the survey form.
\end{abstract}

\title{
Geotechnical Engineering Testings
}

\section{Sample Recruitment:}

Sample recruitment is obtained properly so that they will not be blemished which will have an effect on the results of experiment. Disturbed and undisturbed soil sample are taken from the selected site. Sample is taken from the depth of 5 metres and top soil that contains roots of the plant and humus from the decay should remove. Samples which are excavated more than $5 \mathrm{~m}$ depth are used for laboratory test and for further analysis (Muzamir, 2005).

\section{Physical Clay Experiment:}

Physical test is important to provide recommendations current drainage systems improvements. The tests being conducted are sieve analysis, moisture content, Atterberg limit and specific gravity test which are based on BS 1377: Part 2:1990.

\section{Shear Strength Experiment (BS 1377: Part 7: 1990):}

Strength is the measurement of maximum stress on a material. The main purpose of this experiment is to obtain the soil strength based on the failure coverage and tensile strength (Muzamir, 2005). 


\section{Probe JKR test:}

Probe Mackintosh or probe JKR is a method to investigate bearing capacity of soil at an early stage. It is the cheapest and often used method on site. It gave the quick, easy and cheap results compared to the others.

\section{Data Collection:}

From the results of lab test and site test, the data is gathered and analyzed. The data obtained are includes soft clay characteristics and shear strength.

\section{Data and Analysis:}

The plotted data have been analyzed and compared from the standard value and existing result. All the data from the analysis used for making the model using slope/w software. From the analysis result, a suitable method is selected for improving the effectiveness of drainage system in rural road that build on soft clay.

\section{Pavement Condition Index}

\section{Result Analysis}

Bar chart in Figure 3 shows the percentages of road pavement damages type at rural road in Parit Raja which involve 14 rural roads along Parit Raja to Parit Karjo. Most of the damage type is the Alligator's Cracks with $24.41 \%$ among damage types. This type of crack causes by surface pavement failure that cannot support the load on it. Crack usually started from below pavement surface which experiences high tension stress and strain when the load of vehicle placed on it (Rigo et al., 1993).

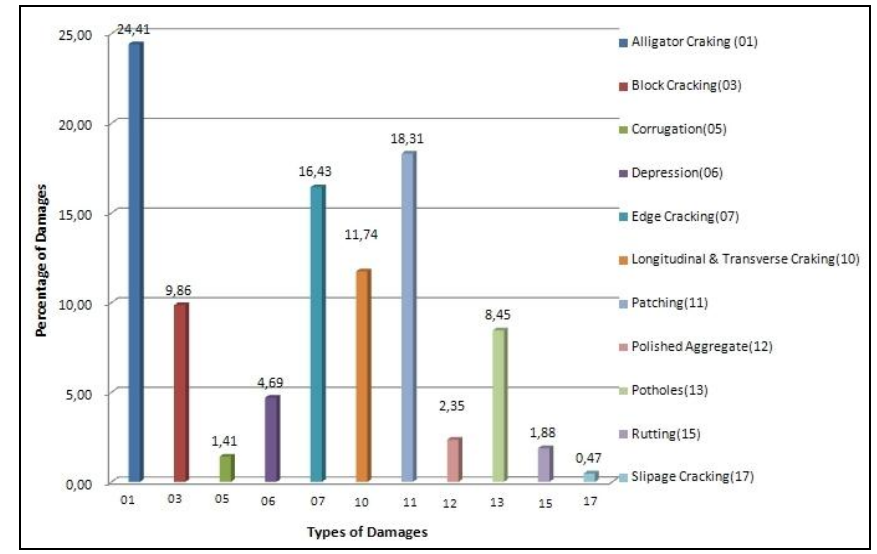

Figure 3: Percentage of the number of road pavement damages versus type of pavement damages

\section{Geotechnical Testings}

In-situ Analysis - Probe Mackintosh:

Based on Table 1 and 2, the highest value of bearing capacity of soil at Parit Karjo is $64 \mathrm{kN} / \mathrm{m}^{2}$ and for Parit Sempadan is $68 \mathrm{kN} / \mathrm{m}^{2}$. If the result compared with estimated bearing capacity value in the BS 8004: 1986 (value of bearing capacity for soft clay and silt is $75 \mathrm{kN} / \mathrm{m}^{2}$ or less), it shows these values of bearing capacity is in the range.

Table 1: Average of soil bearing capacity for every soil layers at Parit Karjo

\begin{tabular}{cccc}
\hline \multirow{2}{*}{ Area } & \multicolumn{3}{c}{ Soil Bearing Capacity $\left(\mathbf{k N} / \mathbf{m}^{2}\right)$} \\
\cline { 2 - 4 } & Parit Karjo 1 & Parit Karjo 2 & Avarage \\
\hline First Layer & 15 & 15 & 15 \\
\hline Second Layer & 25 & 35 & 30 \\
\hline Third Layer & 50 & 78 & 64 \\
\hline
\end{tabular}

Table 2: Average of soil bearing capacity for every soil layers at Parit Sempadan

\begin{tabular}{cccc}
\hline \multirow{2}{*}{ Area } & \multicolumn{3}{c}{ Soil Bearing Capacity $\left(\mathbf{k N} / \mathbf{m}^{\mathbf{2}}\right)$} \\
\cline { 2 - 4 } & Parit Karjo 1 & Parit Karjo 2 & Avarage \\
\hline First Layer & 15 & 15 & 15 \\
\hline Second Layer & 25 & 35 & 30 \\
\hline Third Layer & 50 & 78 & 64 \\
\hline
\end{tabular}




\section{Moisture Content:}

\section{Result of Laboratory Testing}

Type of the soil sample is disturbed sample that taken at $0.5 \mathrm{~m}$ depth. From the test at Parit Karjo and Parit Sempadan show the average moisture content at Parit Karjo is $110.57 \%$ and $126.85 \%$ for Parit Sempadan. If these results are compared to Balasubramaniam et al. (1985) research, (moisture content for soft clay in Malaysia is 20 to $175 \%$ at the West Peninsular Malaysia and 21 to $170 \%$ at the East Peninsular Malaysia, respectively), those values are in the range.

\section{Atterberg Limits:}

(i) Liquid Limit

The value of liquid limit is $58.69 \%$ for soil at Parit Karjo and $66.5 \%$ at Parit Sempadan. The obtained values of liquid limit are in the range of 31 to $142 \%$ which is for clay as mentioned by Saiful (2004).

(ii) Plastic Limit

From the test, the plastic limit for every soil sample at Parit Karjo and Parit Sempadan is $37.3 \%$ and $41.11 \%$, respectively. If the result compared to the research by Saiful (2004), the values are in the range 14 to $42 \%$ which is for clay.

\section{Soil Classification:}

By determining the value of liquid limit and plasticity index for tested soil sample, plasticity chart can be used to group soil classification that has same characteristics. From the plasticity chart in Figure 4, both tested sample can be classified as soft clay and silt with high plasticity (MH) (Mohd Haizam, 2005).

\section{Specific Gravity:}

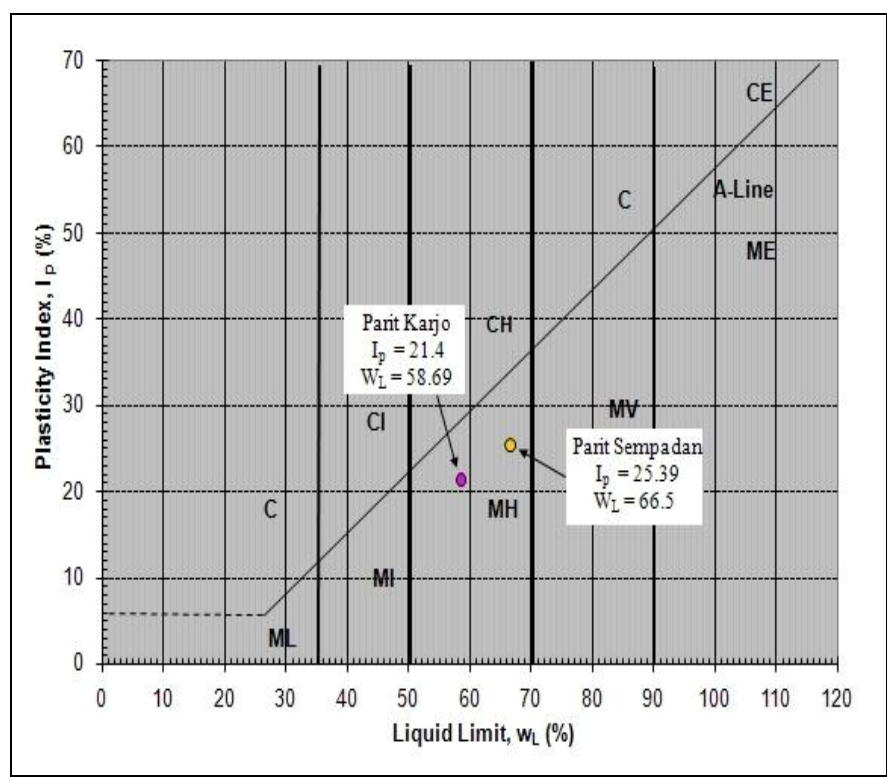

Figure 4: British System Chart Plasticity (BS 5930: 1981)

From the result, the value of specific gravity at Parit Karjo is 2.61 and at Parit Sempadan is 2.59. According to Bowles (1978), the specific gravity for organic soil category has a value ranging from 1 to 2.6. The values obtained are acceptable when compared to the previous research done by Mohd Haizam (2005).

\section{Hydrometer:}

The hydrometer test is to determine the soil particle size. From the test done, the soft clay in Parit Karjo contains $10 \%$ clay, $45.8 \%$ silt and $29.8 \%$ sand. For soil in Parit Sempadan, it contains 9\% clay, $54.8 \%$ silt and $27.2 \%$ sand. The range values for clay, silt and sand are from 7 to $30 \%, 49$ to $69 \%$ and 4 to $35 \%$, respectively (Saiful, 2004).

\section{Direct Shear Test:}

Cohesion Value c, and friction angle, $\phi$ at Parit Karjo and Parit Sempadan are $16.7 \mathrm{kN} / \mathrm{m}^{2}$ and $20.8^{\circ}$, and $6.38 \mathrm{kN} / \mathrm{m}^{2}$ and $24.5^{\circ}$, respectively. In summary, values for shear strength at Parit Karjo and Parit Sempadan are in range of $6 \mathrm{kN} / \mathrm{m}^{2}$ to $17 \mathrm{kN} / \mathrm{m}^{2}$ and $20^{\circ}$ to $25^{\circ}$ for friction angle. Flodin dan Broms (1981) found that the shear strength for soft clay is less than $25 \mathrm{kN} / \mathrm{m}^{2}$ and therefore, proven that soil type in Parit Karjo and Parit Sempadan are soft clay.

\section{Slope/W Analysis}

Figure 5 shows the value of Factor os Safety (FOS) versus Loading. The value of FOS increases according to the different loading. For the case study of 1, 4, 6 and 7, the FOS values are more than 1.2 and from the values, 
it show that the slope for the cases is safe. However, case study 2 shows the FOS value of not more than 1.2 and therefore, the slope is not safe.

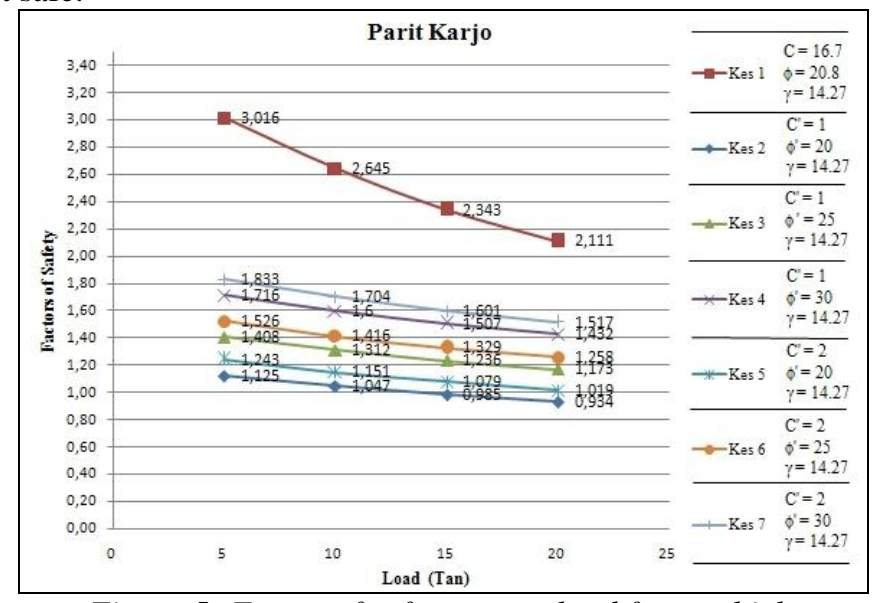

Drainage Failure Area

Figure 5: Factor of safety versus load from vehicle

There are six locations having the drainage failure. Location area L1, L2 and L3 is at Jalan Parit Raja, location area L4 is at Jalan Parit Daun while the location area L5 is at Jalan Parit Sempadan and last location area is L6 at Jalan Parit Karjo. Based on the inspection that has been done at the study location, identification of the types of failure on a road surface which occur to the drainage failure is carried out. Types of road surface failure identified are alligator cracking, Longitudinal cracking, Edge cracking and potholes. The natural moisture content of soil at these locations is between 34 to $78 \%$ and plastic limit is between 37 to $64 \%$. Table 3 shows the summary of results.

Table 3: Relationship between drainage failures with surface failure of the road

\begin{tabular}{|c|c|c|c|c|}
\hline Location & Types of drainage failure & $\begin{array}{c}\text { Types of road surface } \\
\text { failure }\end{array}$ & $\begin{array}{l}\text { Natural } \\
\text { Moisture } \\
\text { Content }\end{array}$ & Plastic Limit \\
\hline \multirow{3}{*}{ L 1} & \multirow{3}{*}{ Drainage edge drop } & Alligator cracking & \multirow{3}{*}{$34.76 \%$} & \multirow{3}{*}{$37.38 \%$} \\
\hline & & Longitudinal cracking & & \\
\hline & & Edge cracking & & \\
\hline \multirow[b]{2}{*}{$\mathrm{L} 2$} & \multirow{2}{*}{$\begin{array}{l}\text { Soil Movement To Side } \\
\text { Road }\end{array}$} & Alligator cracking & \multirow[b]{2}{*}{$49.09 \%$} & \multirow[b]{2}{*}{$54.39 \%$} \\
\hline & & Edge cracking & & \\
\hline \multirow[b]{2}{*}{ L 3} & \multirow{2}{*}{$\begin{array}{l}\text { Soil Movement To Side } \\
\text { Road }\end{array}$} & Alligator cracking & \multirow[b]{2}{*}{$56.10 \%$} & \multirow[b]{2}{*}{$44.03 \%$} \\
\hline & & Edge cracking & & \\
\hline \multirow[b]{2}{*}{$\mathrm{L} 4$} & \multirow{2}{*}{$\begin{array}{l}\text { Soil Movement To Side } \\
\text { Road }\end{array}$} & Alligator cracking & \multirow[b]{2}{*}{$77.36 \%$} & \multirow[b]{2}{*}{$63.39 \%$} \\
\hline & & Edge cracking & & \\
\hline \multirow[b]{2}{*}{ L 5} & \multirow[b]{2}{*}{ Edge Drainage Crack } & Alligator cracking & \multirow[b]{2}{*}{$52.95 \%$} & \multirow[b]{2}{*}{$41.11 \%$} \\
\hline & & Longitudinal cracking & & \\
\hline \multirow{3}{*}{ L 6} & \multirow{3}{*}{ Drainage edge drop } & Alligator cracking & \multirow{3}{*}{$39.67 \%$} & \multirow{3}{*}{$37.30 \%$} \\
\hline & & Longitudinal cracking & & \\
\hline & & Potholes & & \\
\hline
\end{tabular}

\section{Soil Drainage Failures Category}

\section{Soil Movement:}

This failure is caused by the movement of soil to another side and the property of soil. The laboratory and insitu testings show that the soil at Parit Sempadan and Parit Karjo can be classified as clay soil and silt with high plasticity. According to Bell (1981), clay soil have low shear strength and can make spin slide. Soil movement to other side shows the spin slide case. Beside than that, the poor construction of rural road structure is another reason of this failure. Figure 6 shows the soil movement to road side. 


\section{Drainage Side Drop:}

The second failure is happened when the soil at edge road fall that because the property of soil is soil clay, as shown in Figure 7. Soil clay usually has small void and porosity that cause it have high detention water. Therefore, soil clay usually shrinks and expands and able to create slide and crack to the soil properties. The side drainage part usually will shrink first because this part is wide open to sun and soil's below is slowest to shrink that contributes to slide and cracking. Moreover, the load from vehicle can creates more defects to the road structure.

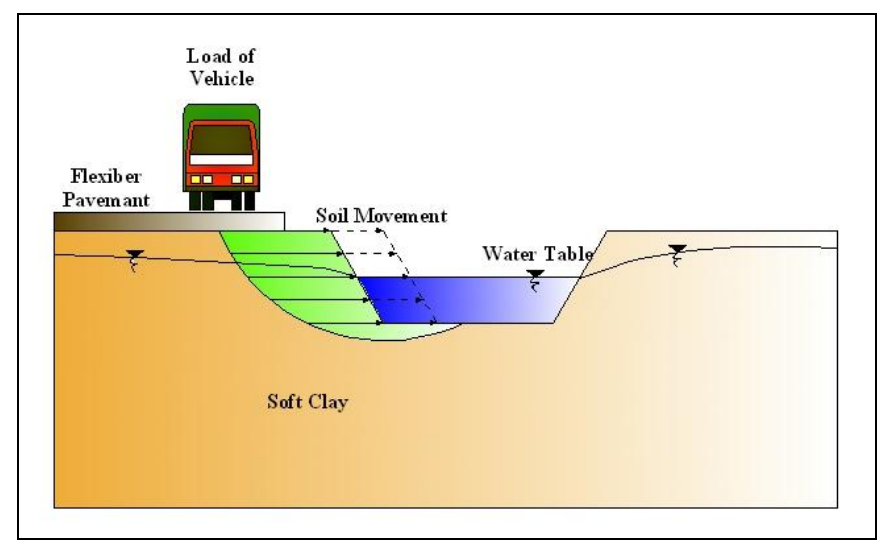

Figure 6: Soil Movements to Road Side

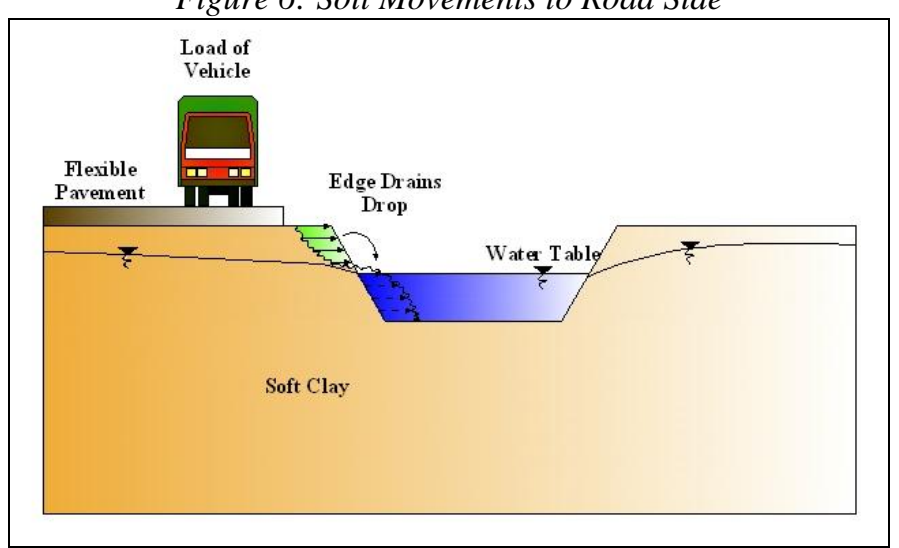

Figure 7: Drainage Side Drop

Edge Drainage Crack:

The defect at the edge drainage crack, as shown in Figure 8, is more similar to drainage side drop but the difference is this crack is filled with water. Hydrostatic force acts normally to crack that full with water. This situation causes the crack to expand and slope slide will occur.

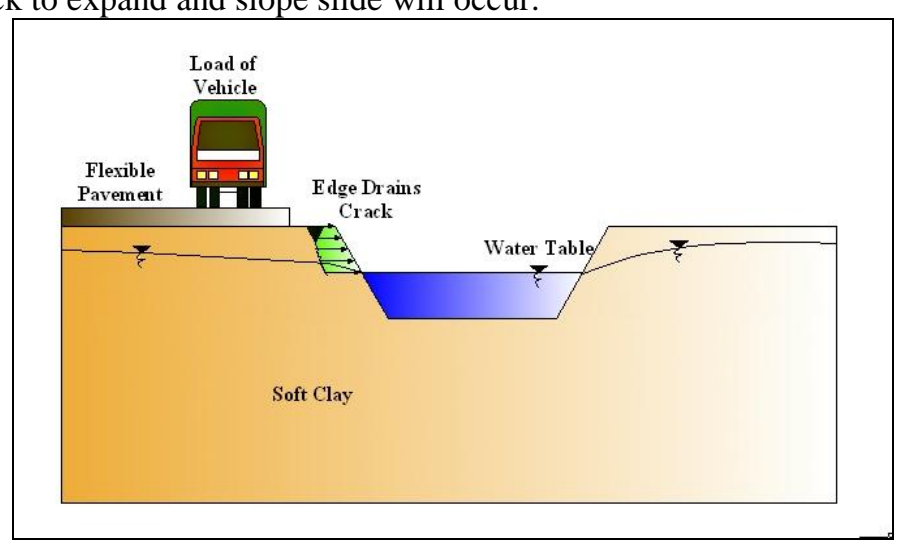

Figure 8: Edge Drainage Crack

\section{Slope Drainage Erosion:}

This defect is due to the presence of high water flow in the drainage. Erosion will occur when soil clay is saturated, as shown in Figure 9. Usually erosion will easily takes place in clayey soil with sand. The erosion also causes the slope at the side of the drain to fail. 


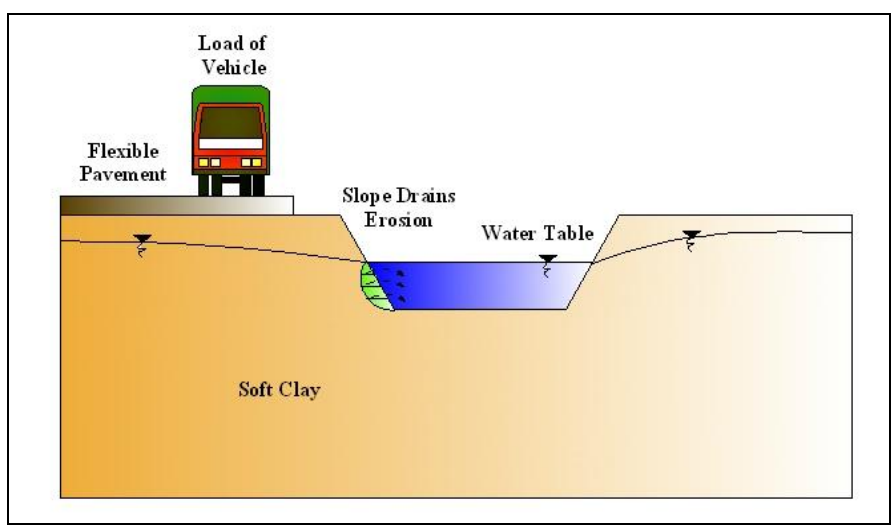

Figure 9: Slope Drainage Erosion

Methods to Improve Effectiveness of Rural Road Drainage System

\section{Geotextiles:}

By using geotextiles, it can increase the soil shear strength by acting as a binding agent. Geotextiles also guard the slope from erosion by guiding the water flow in the structure as well as water channel. Figure 10 shows the use of geotextiles as material for slope stability (Abdul Rahim, 2005).

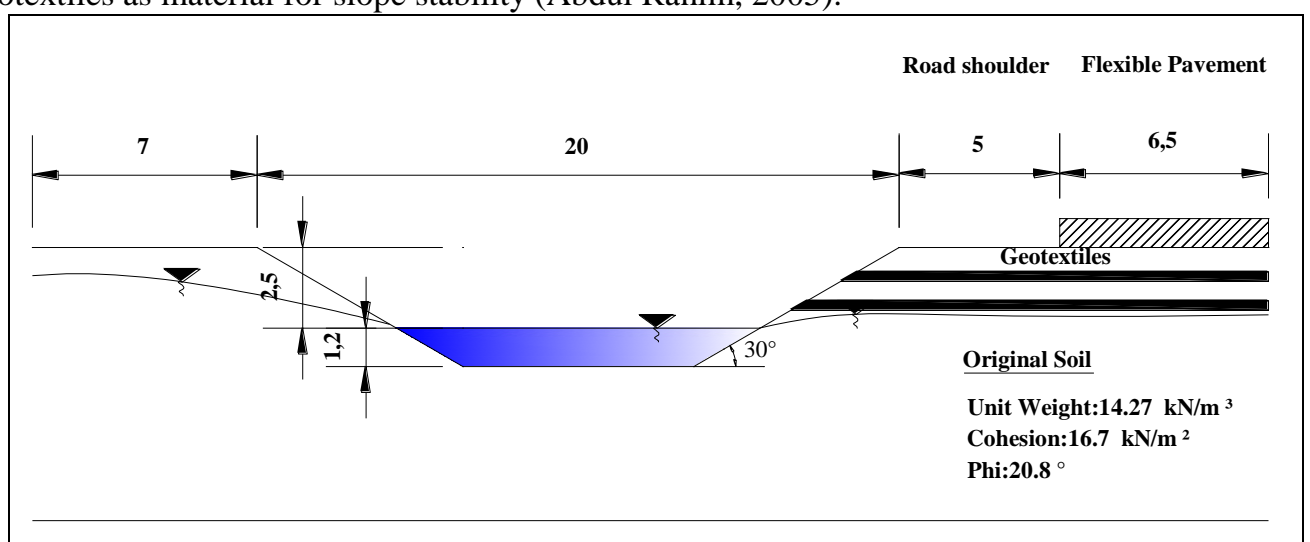

Figure 10: Geotextiles as Material for Slope Stability

\section{Combination of Geocontainers and Geotextiles:}

Combination of geocontainers and geotextiles, as shown in Figure 11, will avoid soil movement that caused by heavy load as well as to increase the soil shear strength. Geocontainers is made by mixing sand and asphalt. In this method, the geotextiles will function as anchor to geocontainers to stabilize it. Sand will be filled underneath the geotextiles to avoid the geocontainers settlement (Van \& Verastegui, 2007).

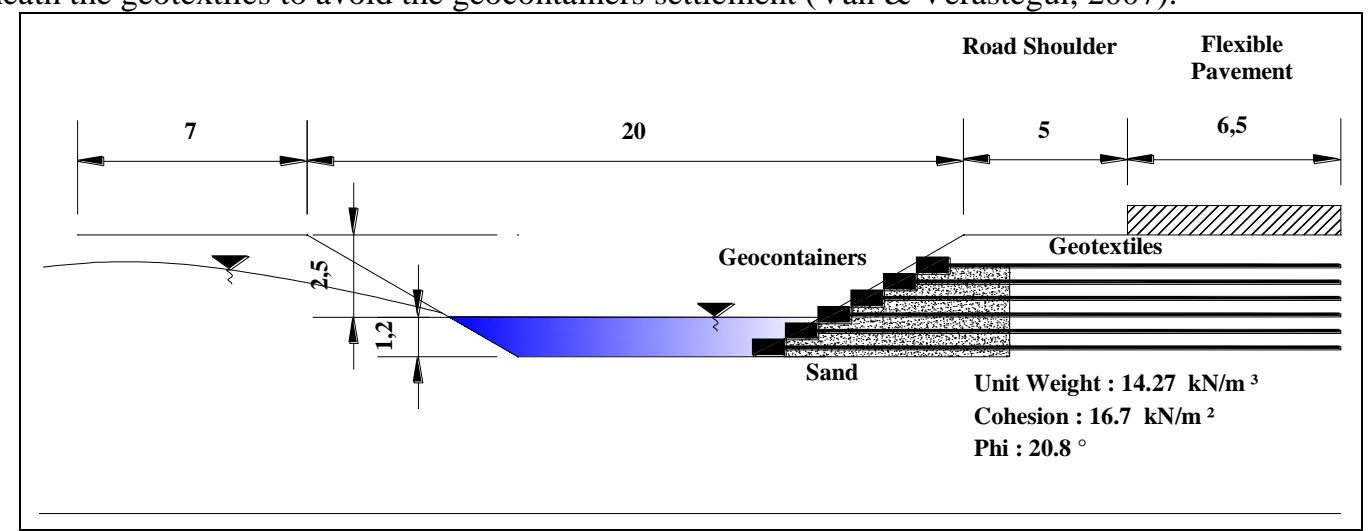

Figure 11: Combination of Geocontainers and Geotextiles as Material for Slope Stability

Anchored in Soil Clay:

The easier method is to anchor the soil clay by excavating a hole to the suitable depth, put the tendon and lay along the anchor by using tremi pipe, as shown in Figure 12. In order to increase the effectiveness of the anchor, gravel injection technique can be employed, after which a 'selongsang' is fixed with sharp shoe is piled into the soil clay. After that, the tendon will be injected and laid into the gravel when 'selongsang' or tube is taken-out (Craig, 1993). 


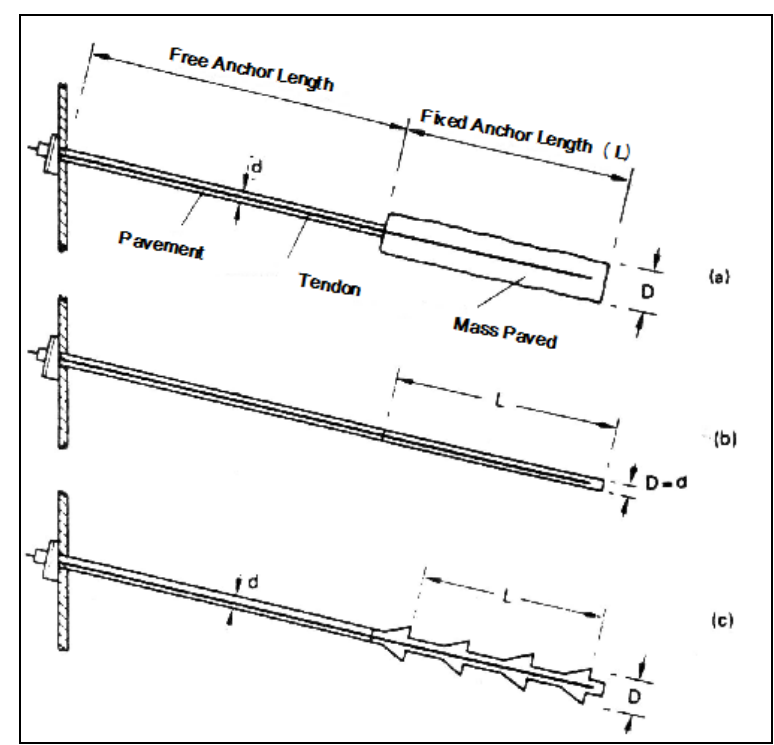

Soil Stabilization Using Lime:

Figure 12: Anchored in Soil Clay

This method is carried out by using burn lime, quick lime and hydrated lime. Hydrated lime is used because of availability and safe to use. Lime is a high alkali base that has chemistry reaction with clay soil. Calcium ion will displace cat-ion to make complex silicates or cementing materials (Dzulkarnain, 2007).

\section{Conclusion}

In conclusion, the roadside drainage failures in study locations can be categorized as soil movement, edge drop, cracking and erosion. The drainage failure is also due to the soil properties which are soft, low shear strength, and high compressibility. Soil expansive property in nature when in contact with water and later experience shrinkage effect and when allowed to dry could subsequently contribute towards drainage slope failure. Another cause of failure to the drainage system is the agriculture heavily loaded trucks that occasionally running through the rural roads.

The low quality construction materials used to construct the rural roads is also contributing the road failures and subsequently, water intruded into the road structure and seep through into the side of the drains. Consequently, cause the drainage system failure. The application of stabilization materials such as geomembrane, geo-textiles, geo-synthetic clay liners, geo-containers and geo-grids are suggested in order to overcome the problem due to soft clay.

\section{References}

[1]. Abdul Rahim bin Awang. (2005). Keupayaan Galas Tanah Liat Lembut Bertetulang Menggunakan Gabungan Buluh-Geotekstil. Master Thesis, Universiti Teknologi Malaysia

[2]. Azman bin Hasan. (1999). Analisis Kerosakan Turapan Jalan Kampung Di Dalam Daerah Batu Pahat Dan Peyimpanan Data Cerapan Dengan Perisian Viroads. Institut Teknologi Tun Hussein Onn, Bachelor Dissertation, Universiti Teknologi Malaysia

[3]. Brand, E.W. and Brenner, R.P. (1981). Soft Clay Engineering. Elsevier Scientific Publishing Company, Amsterdam

[4]. Craig, R.F. (1993). Mekanik Tanah. Terjemahan Soil Mechanics oleh Aminaton Marto, Fatimah Mohd Noor, dan Fauziah Kasim Edisi ke-4. Unit Penerbitan Akademik Universiti Teknologi Malaysia

[5]. Dzulkarnain bin Razak. (2007). Effect of Temperature to Soil Stabilized With Lime. Bachelor Dissertation, Universiti Teknologi Malaysia

[6]. Flodin, N. and Broms, B. (1981). Historical Development of Civil Engineering in soft clays. Elsevier Scientific Publishing Company

[7]. Liang Chin Yeen. (2001). Kajian Kerosakan Permukaan Turapan Jalan Raya Di Sepanjang Jalan Utama dari Batu Pahat Ke Ayer Hitam. Institut Teknologi Tun Hussein Onn, Bachelor Dissertation, Universiti Teknologi Malaysia

[8]. Mohd Haizam. (2005). Ciri-ciri Kebolehmampatan dan Kekuatan Tanah Liat Lembut di KUiTTHO.: Bachelor Dissertation, Kolej Universiti Teknologi Tun Hussein Onn

[9]. Mohd Idrus bin Mohd Masirin. (2006). Performance Evaluation of Encapsulated Road Pavement on Difficult Ground Condition. PhD Thesis. University of East Landon, U.K.

[10]. Muzamir bin Hasan. (2005). Penyiasatan Tanah, Pemsempelan,dan Kekuatan Ricih Tanah Liat Lembut. Bachelor Dissertation, Universiti Teknologi Malaysia

[11]. Rigo, J.M., Degeimbre, R., and Francken, L. (1993). Reflective Cracking in Pavements. London: Chapman \& Hall

[12]. Saiful Azhar. (2004). Ciri-ciri Kejuruteraan Tanah Liat Lembut di Semenanjung Malaysia. Bachelor Dissertation, Universiti Teknologi Malaysia

[13]. Van, I.W.F. and Verastegui, F.R.D. (2007). Underwater Embankments on Soft Soil. Taylor \& Francis Group, London, U.K. 